\title{
Generating Cloned Goats by Somatic Cell Nuclear Transfer-Molecular Determinants and Application to Transgenics and Biomedicine
}

\author{
Maria Skrzyszowska *,+(D) and Marcin Samiec *,+(D) \\ Department of Reproductive Biotechnology and Cryoconservation, National Research Institute of \\ Animal Production, Krakowska 1 Street, 32-083 Balice n. Kraków, Poland \\ * Correspondence: maria.skrzyszowska@iz.edu.pl (M.S.); marcin.samiec@iz.edu.pl (M.S.) \\ + These authors contributed equally to the preparation of this paper.
}

Citation: Skrzyszowska, M.; Samiec,

M. Generating Cloned Goats by

Somatic Cell Nuclear

Transfer-Molecular Determinants and Application to Transgenics and Biomedicine. Int. J. Mol. Sci. 2021, 22, 7490. https://doi.org/10.3390/ ijms22147490

Academic Editor: Sato Masahiro

Received: 11 June 2021

Accepted: 9 July 2021

Published: 13 July 2021

Publisher's Note: MDPI stays neutral with regard to jurisdictional claims in published maps and institutional affiliations.

Copyright: (c) 2021 by the authors. Licensee MDPI, Basel, Switzerland. This article is an open access article distributed under the terms and conditions of the Creative Commons Attribution (CC BY) license (https:/ / creativecommons.org/licenses/by/ $4.0 /)$.
Abstract: The domestic goat (Capra aegagrus hircus), a mammalian species with high genetic merit for production of milk and meat, can be a tremendously valuable tool for transgenic research. This research is focused on the production and multiplication of genetically engineered or genomeedited cloned specimens by applying somatic cell nuclear transfer (SCNT), which is a dynamically developing assisted reproductive technology (ART). The efficiency of generating the SCNT-derived embryos, conceptuses, and progeny in goats was found to be determined by a variety of factors controlling the biological, molecular, and epigenetic events. On the one hand, the pivotal objective of our paper was to demonstrate the progress and the state-of-the-art achievements related to the innovative and highly efficient solutions used for the creation of transgenic cloned does and bucks. On the other hand, this review seeks to highlight not only current goals and obstacles but also future challenges to be faced by the approaches applied to propagate genetically modified SCNTderived goats for the purposes of pharmacology, biomedicine, nutritional biotechnology, the agri-food industry, and modern livestock breeding.

Keywords: domestic goat; somatic cell cloning; SCNT-derived embryo; genetically engineered specimen; gene targeting; genome editing; biopharmacy; biomedicine; nutri-biotechnology

\section{Introduction}

One of the most rapidly developing strategies for reproductive biotechnology in mammals, including farm livestock species, is cloning by somatic cell nuclear transfer (SCNT) (Figure 1).

It is beyond any doubt that the attractiveness of cloning techniques results from their potential to generate and multiply transgenic animals, which are valuable due to the expression of modified genes (Figure 1). Furthermore, this attractiveness also depends, to a lesser degree, on the possibility to replicate individuals with excellent, highly heritable breeding (genetic) and performance traits, which may shorten the generation interval and increase the rate of breeding progress. However, the aforementioned areas of research are being explored on a limited scale due to the high costs associated with the cloning procedure resulting from the low efficiency of the method. It is beyond any doubt that the widespread use of cloning methods will be possible once efficacy and repeatable results are guaranteed [1-4].

The main reason for low pre- and postimplantation developmental potential and poor quality of SCNT-derived embryos is the abnormal adaptation of the transferred somatic cell nuclei to the biochemical conditions of the oocyte cytoplasmic microenvironment, i.e., their incomplete or improper remodeling and reprogramming in the cytoplasm of nucleartransferred oocytes. The latter also gives rise to the relatively high incidence of congenital malformations (anatomo-, histo-, and physiopathological changes) in cloned fetuses and 
offspring. This calls for studies aimed at the precise determination of the conditions that facilitate epigenetic reprogramming in the nuclear donor cell genome during the preand postimplantation development of SCNT-generated embryos and fetuses of different mammalian species, including the domestic goat [5-10]. Promising results were achieved by investigations that focused on the use of extrinsic nonselective agents for stimulating the epigenetically regulated transcriptional activity of genomic DNA in both nuclear donor somatic cells and SCNT-cloned embryos [11-15].

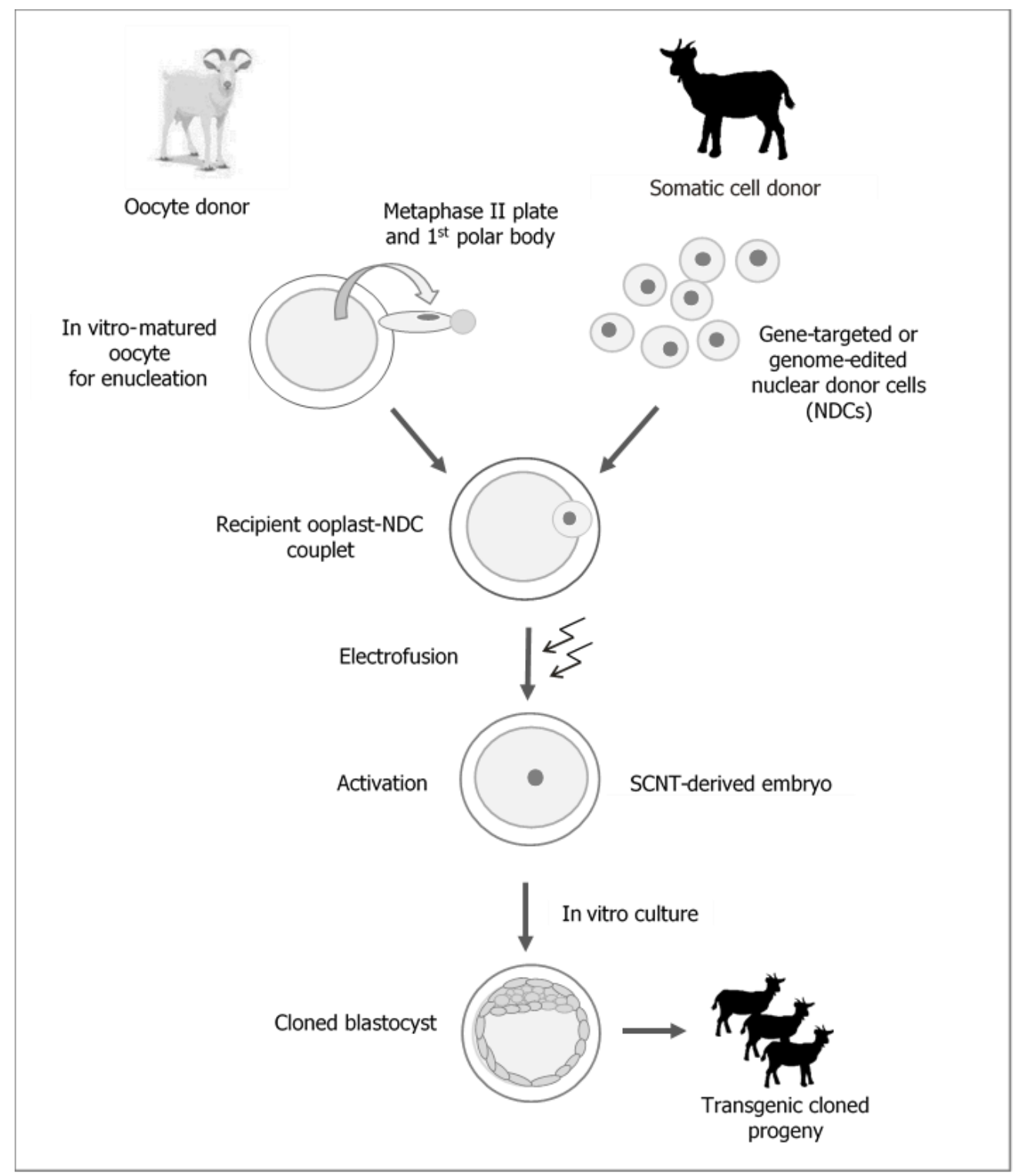

Figure 1. Generation of transgenic cloned goats by somatic cell nuclear transfer (SCNT).

2. Key Issues Related to Biological, Molecular, and Epigenetic Determinants Affecting the Efficacy of Somatic Cell Cloning in Goats

The provenance of somatic cells is a factor that can have a significant impact on cloning efficiency in goats. Relatively few types of nuclear donor cells have been tested for their suitability for the production of cloned embryos, fetuses, and/or offspring in this livestock species. Those that have been tested include cells stemming from several types of tissues collected from both caprine fetuses and adult animals of both sexes and of different ages. Among the nuclear donor cells (NDCs) used for SCNT procedures, mention should be made of: (1) in vitro cultured (transgenic or nontransgenic) fetal dermal fibroblasts [12,16-22]; 
(2) juvenile and adult dermal fibroblasts [14,23-26]; (3) mural granulosa cells isolated from antral ovarian follicles [18,27]; (4) cumulus oophorus cells [18,27,28].

Special consideration should be given to the use of pituicytes, i.e., endocrine cells originating from the anterior pituitary (also known as adenohypophysis) of postpubertal bucks, as a source of nuclear donors for SCNT in goats [29]. To date, this cerebral tissue-specific type of endocrine cell, which synthesizes and secretes tropic hormones, has not been used for SCNT in other species of farm and laboratory animals. It has been postulated, however, that artificial (ectopic) control of metabolic and secretory activities of the endocrine compartment in all lobes of the pituitary gland of livestock species might be feasible through genetic modification (transfection) of pituicytes at the in vitro culture level. In turn, utilizing genetically transformed pituitary-derived glandular cells, which are characterized by inducible expression of recombinant human hormonal proteins or polypeptides, for the generation of transgenic specimens of different mammalian species by somatic cell cloning opens up a variety of new application opportunities. The latter encompass the production of transgenic animal bioreactors, which provide xenogeneic (human) tropic hormones in cytosol extracts (homogenates) of pituicytes or in blood plasma. These hormones are indispensable for the clinical application of therapies for many human monogenic diseases, which induce endocrine-mediated congenital malformations. The transfer of caprine SCNT embryos that had been reconstructed with pituicytes into the reproductive tract of hormonally synchronized recipient females resulted in the birth of a cloned male kid. The results of these experiments confirmed that even the nuclear genome of terminally differentiated somatic cells such as pituicytes can successfully undergo the complete processes of epigenetic remodeling and reprogramming in pre- and postimplantation cloned goat embryos [29].

Deng et al. [30] examined the methylation profile and expression level of the Xist (X-inactive specific transcript) gene in the cells of SCNT embryos and in ear fibroblast cells, lung-derived cells, and cerebral cells collected from deceased cloned goats. The methylation profile observed for the Xist gene, which is transcribed into a noncoding mRNA molecule, i.e., a transcript that does not exhibit translational activity, was higher in 8-blastomere-stage SCNT embryos as compared to their in vitro-fertilized embryo counterparts generated by intracytoplasmic sperm injection (ICSI). Moreover, an increased methylation profile of the Xist gene was observed in the cells stemming from explants representing tissues/organs such as conchal skin, lungs, and brain, isolated postmortem from dead 3-day-old cloned female kids in relation to naturally bred specimens. While for ear skin-derived tissue bioptates originating from live cloned does, and for lung and brain tissue samples retrieved from dead cloned kids, the methylation profile of $5^{\prime}$-cytidine$3^{\prime}$-monophopshate-5'-guanosine-3' (CpG) islands within the differentially methylated regions/imprinting control regions (DMRs/ICRs) of the Xist gene remained unchanged. Therefore, the transcriptional activity of the Xist gene diminished remarkably in the lungs and brain of dead cloned does, resulting in a lack of inactivation recognized for one of the $\mathrm{X}$ chromosomes (either of paternal or of maternal origin) in the cells of the previously indicated organs. In turn, a significant increase in Xist gene expression was shown in the ear-derived cutaneous fibroblast cells of live cloned does. This contributed to the normal inactivation of one of the two $X$ chromosomes in these specimens. It is evident from this study that an increased incidence of hypermethylation and transcriptional suppression of the Xist gene, and thus no inactivation of one of the two X chromosomes, or in other words, active initiation of enhanced transcriptional activity (i.e., biallelic overexpression) of the genes localized in the loci of the paternal and maternal $\mathrm{X}$ chromosomes occurred in caprine SCNT-derived female fetuses. For these reasons, the aforementioned processes, which were also identified in the tissue explants recovered from 3-day-old dead cloned does, are found to arise from incomplete and aberrant reprogramming and were highlighted as a result of the epigenetically determined transcriptional activity of the somatic cell nuclear genome in cloned goat embryos [30]. 
Incomplete or incorrect epigenetic reprogramming of epigenetic memory, which is encoded in extragenic covalent modifications of the somatic cell nuclear genome, was found to be one of the main factors decreasing the efficiency of somatic cell cloning in mammals, including the domestic goat. Reductions in this efficiency are reflected in the weakened in vitro and/or in vivo developmental potential of SCNT-derived embryos [7,8,31]. Methylation of cytosine residues in CpG islands/dinucleotides is a widely explored/recognized modification of the somatic cell nuclear genome in cloned embryos $[6,9,10,32]$. Han et al. [33] demonstrated that enzymatic activity of ten-eleven translocation methylcytosine dioxygenase 3 (TET3) is a key molecular mechanism underlying active DNA demethylation in preimplantation goat embryos created by somatic cell cloning. Knocking out the TET3 gene led to the inhibition of active (i.e., DNA replicationindependent) demethylation of 5-methylcytosine (5-mC) residues in 2-blastomere-stage cloned goat embryos. As a consequence, this brought about the downregulation of the expression of the pluripotency-related Nanog gene in the inner cell mass (ICM) compartment of the generated blastocysts. In turn, overexpression of the TET3 gene that had been induced by transgenization of in vitro cultured somatic cells resulted in: (1) abundant demethylation of DNA 5-mC residues; (2) declined quantitative profile of 5-mC moieties; (3) increased incidence of 5-hydroxymethylcytosine residues; (4) intensified transcriptional activity of crucial pluripotency-related genes. Furthermore, the use of genetically transformed somatic cells displaying overexpression of the TET3 gene-as nuclear donors for the reconstruction of caprine enucleated oocytes-contributed to an enhancement in the extent of active demethylation of 5-mC residues within somatic cell-inherited nuclear DNA. The latter perpetuated hypomethylation of the somatic cell-derived genome in cleaved SCNT embryos, subsequently triggering remarkable improvements in their in vitro and in vivo developmental capabilities. It follows that overexpression of the TET3 gene in NDCs significantly ameliorates the efficacy of somatic cell cloning in goats.

The developmental potential of the mammalian SCNT embryos, including their caprine representatives, which inherit the somatic cell nuclear genome as a result of the reconstruction of enucleated oocytes, is highly dependent on the level of epigenetic modifications within DNA and chromatin-derived histones of the NDCs undergoing longterm in vitro culture [34-36]. One of the strategies to reverse advanced alterations in the pattern of epigenetic covalent modifications within somatic cell nuclei, which encompass rapid DNA methylation and a decrease in the quantitative profile of histone protein acetylation, appears to be the exposure of NDCs, SCNT-derived oocytes, and corresponding embryos to reversible agents inhibiting biocatalytic activity of DNA methyltransferases (DNMTs) and/or histone deacetylases (HDACs). The use of nonselective or selective promoters of epigenetically determined transcriptional activity of genomic DNA in both in vitro cultured NDCs and cloned embryos is supposed to be an approach that allows for proper reprogramming of somatic cell nuclei $[7,12,14]$. Exogenously modulating the epigenetic memory profile of genomic DNA appears to contribute to successfully reversing the "transcriptional clock" of a differentiated somatic cell nucleus to the status of a cell nucleus characteristic of a totipotent or pluripotent embryonic cell. As a consequence, such efforts induce the restoration of the expression pattern that is seen in genes that are inevitable in the initiation and progress of the developmental program of SCNT-derived embryos $[37,38]$. This results in a reduction in the methylation degree of DNA cytosine residues and an increase in the acetylation of nuclear chromatin histone proteins [39,40]. In turn, the previously specified processes were shown to bring about recapitulation and perpetuation of the correct and faithful profiles of transcriptional activities observed both for the genes indispensable to induce and maintain the totipotency/pluripotency states and for the genes encoding enzymes responsible for endogenous epigenetic modifications during pre- and postimplantation embryogenesis. The totipotency/pluripotency-related genes encompass those that encode such proteins as: e.g., octamer-binding transcription factor $3 / 4$ (Oct3/4), the homeobox-containing transcription factor Nanog, whose name stems from the Celtic/Irish mythical word Tír na nÓg (i.e., The Land of the Ever-Young), DNA- 
binding proto-oncogenic/oncogenic transcription factor c-Myc, sex-determining region $Y$ (SRY)-box 2 transcription factor (Sox2), Krüppel-like factor 4 (Klf4), reduced expression protein 1 (Rex1), and caudal-type homeobox protein $2(\mathrm{Cd} 2)$. The epigenetic modifier genes involve those that encode such enzymatic proteins as: e.g., DNA methyltransferase type 1 (DNMT1), DNA methyltransferase type 3a (DNMT3a), DNA methyltransferase type $3 \mathrm{~b}$ (DNMT3b), histone deacetylase type 1 (HDAC1), histone deacetylase type 2 (HDAC2), histone methyltransferase (HMT), and histone acetyltransferase (HAT) [3,41,42]. In the wake of recent research, innovative and highly efficient methods were developed to modulate the epigenetic memory profile of mammalian SCNT embryos, including their caprine counterparts. These methods are focused on applying exogenous nonselective HDAC inhibitors (such as trichostatin A, valproic acid, and scriptaid) and/or nonselective DNMT inhibitors (such as 5-aza-2'-deoxycytidine) or selective inhibitors lysine K4 demethylases specific for histones $\mathrm{H} 3$ within the nucleosomal core of nuclear chromatin (such as trans2-phenylcyclopropylamine (tranylcypromine; 2-PCPA)). The aforementioned strategies may considerably modify the epigenetically determined reprogramming of the somatic cell nuclear genome in SCNT-derived embryos. The final results of these innovative solutions turn out to be significant enhancements of the pre- and /or postimplantation developmental competence and an improvement in the molecular quality of cloned embryos in mammals, including the domestic goat [12-14,42-44].

\section{Species-Specific Advantages of the Goat That Increase the Potential for Its Practical} Application in Transgenics, Biopharmacy, Biomedicine, and Biotechnology

The domestic goat (Capra aegagrus hircus), a species with a tremendously high biodiversity of breeds showing relatively high milk and/or meat yield, may serve as an excellent research subject for SCNT-mediated production of transgenic bioreactor specimens. These caprine genetically engineered bioreactors of foreign species-descended (xenogeneic) biopreparations can provide recombinant human therapeutic proteins that are designated as biopharmaceuticals or nutraceuticals (Table 1), together with physiological secretions (e.g., milk) and excreta (e.g., urine). Moreover, somatic cell cloning in this livestock species seems to be a reliable, feasible, and powerful tool for generating and/or multiplying specimens (does and bucks) that display genetically modified parameters of meatiness and intramuscular adipose tissue content (Table 1). Increasing the efficiency of producing purified xenogeneic biopharmaceuticals or bionutraceuticals derived from the mammary glands (udders) of transgenic goats would thus allow them to be phased into the biopharmaceutical industry [24,45]. Another tangible benefit of producing transgenic cloned goats, which appears to be especially valuable for the xenogeneic product of the transgenic expression of exogenous DNA (directed at the mammary glands or resulting in higher meatiness), is the relatively short species-specific generation interval. The latter allows for increasing the rate of genetic progress in the breeding of founder does and bucks $[24,25]$. Yet another advantage of this small ruminant species is the low susceptibility of dairy and meat goats to infection with pathological prions $\left(\mathrm{PrP}^{\mathrm{Sc}}\right)$ that cause scrapie in sheep $[27,46,47]$. Transgenic goats may serve as optimal bioreactors to produce human therapeutic proteins for various agroeconomic reasons. Compared to the breeding of transgenic cows, these animals are more easily farmed, their natural and biotechnologically assisted reproduction can be more rapidly controlled, and they are much cheaper to keep as compared to large ruminants. Relative to their body size, they have fairly large udders with a predominance of glandular tissue over fibrous parenchyma, which makes this small ruminant species genetically predisposed to a high production potential of colostrum and milk. The possible consequence of these anatomo-physiological advantages in goats is the high performance of transgenic doe herds in terms of lactogenic synthesis and secretion of recombinant human therapeutic proteins (biopharmaceuticals or nutraceuticals) by alveolar mammary epithelial cells. These caprine cells provide udder-derived secretion with a genetically modified qualitative and quantitative composition [24,48,49]. 
Table 1. Targets and effects of genetic modification in transgenic cloned goats.

\begin{tabular}{|c|c|c|c|c|c|}
\hline $\begin{array}{c}\text { Target of } \\
\text { Genetic } \\
\text { Modification }\end{array}$ & $\begin{array}{c}\text { Strategy of } \\
\text { Genetic Modification }\end{array}$ & $\begin{array}{l}\text { Method of Somatic } \\
\text { Cell Transfection }\end{array}$ & $\begin{array}{l}\text { Genotypic Effect of } \\
\text { Genetic Modification }\end{array}$ & $\begin{array}{l}\text { Phenotypic Effect of } \\
\text { Genetic Modification }\end{array}$ & Reference \\
\hline \multirow{3}{*}{$\begin{array}{l}\text { Mammary } \\
\text { gland (udder) }\end{array}$} & \multirow{2}{*}{$\begin{array}{l}\text { Gene targeting } \\
\text { (HR-mediated } \\
\text { targeted mutagenesis) }\end{array}$} & Electroporation & $\begin{array}{l}\text { - HR-induced disruption of } \\
\text { caprine the } B L G \text { gene by: } \\
\text { - } \quad \text { either its } \\
\text { monoallelic knockout } \\
\text { or knock-in of the } h L A \\
\text { gene construct into the } \\
B L G \text { exon }\end{array}$ & $\begin{array}{l}\text { - Functionally inactivating the caprine } \\
\text { BLG gene } \\
\text { - Targeted expression of the } h L A \text { gene in } \\
\text { the lactogenic cells of } \\
\text { udder-based bioreactors } \\
\text { - Synthesis of upgraded or humanized } \\
\text { milk without allergenic } \\
\text { (BLG-triggered) properties }\end{array}$ & {$[21]$} \\
\hline & & Lipofection & $\begin{array}{l}\text { - HR-dependent targeted } \\
\text { incorporation of } h L F \text { CDNA into } \\
\text { the nuclear genome (under the } \\
\text { control of the goat } \beta \text {-casein } \\
\text { gene promoter) }\end{array}$ & $\begin{array}{l}\text { - Mammary gland-specific monoallelic } \\
\text { expression of the } h L F \text { gene } \\
\text { - Udder-mediated synthesis of upgraded } \\
\text { or humanized milk } \\
\text { - Production of genetically engineered } \\
\text { milk (GEM) characterized by a broad } \\
\text { spectrum of hLF-induced } \\
\text { immunotherapeutic properties } \\
\text { - GEM properties determined by } \\
\text { antimicrobial, immunomodulatory, } \\
\text { anti-inflammatory, and anticancer } \\
\text { attributes of hLF }\end{array}$ & {$[50,51]$} \\
\hline & $\begin{array}{l}\text { TALEN-mediated } \\
\text { gene editing }\end{array}$ & Electroporation & $\begin{array}{l}\text { - TALEN-dependent targeted } \\
\text { insertion of } h L F \text { cDNA at } B L G \\
\text { locus resulting in: } \\
\text { - } \quad \text { biallelic knock-in of the } \\
h L F \text { coding sequence into } \\
\text { the } B L G \text { exon }\end{array}$ & $\begin{array}{l}\text {-Targeted expression of the } h L F \text { gene in } \\
\text { udder-based bioreactors } \\
\text { - Synthesis of hLF-enriched or } \\
\text { humanized milk } \\
\text { - Production of GEM displaying } \\
\text { immunotherapeutic properties }\end{array}$ & [22] \\
\hline \multirow{5}{*}{$\begin{array}{l}\text { Skeletal } \\
\text { muscles }\end{array}$} & $\begin{array}{l}\text { Gene targeting } \\
\text { (HR-mediated } \\
\text { targeted } \\
\text { mutagenesis) }\end{array}$ & Lipofection & $\begin{array}{l}\text { - Monoallelic knockout } \\
\text { (semi-deficiency) of the MSTN } \\
\text { gene in SCNT-derived progeny }\end{array}$ & $\begin{array}{l}\text { - Inducing hyperplasia and hypertrophy } \\
\text { of striated muscle cells } \\
\text {-Remarkably gaining skeletal muscle } \\
\text { mass and augmenting meatiness by } \\
\text { genetically transforming the muscular } \\
\text { system of heterozygous }\left(\mathrm{MSTN}^{+/-}\right) \\
\text {transgenic cloned offspring }\end{array}$ & [25] \\
\hline & \multirow{2}{*}{$\begin{array}{l}\text { CRISPR/Cas9- } \\
\text { mediated } \\
\text { gene editing }\end{array}$} & Electroporation & $\begin{array}{l}\text { - Monoallelic knockout } \\
\text { (semi-deficiency) of the MSTN } \\
\text { gene in SCNT-derived progeny }\end{array}$ & $\begin{array}{l}\text { - Expression of cellular hyperplasia and } \\
\text { hypertrophy in genome-edited (GE) } \\
\text { skeletal muscle tissue of heterozygous } \\
\left(\mathrm{MSTN}^{+-}\right) \text {transgenic cloned offspring }\end{array}$ & [52] \\
\hline & & Nucleofection & $\begin{array}{l}\text { - Biallelic knockout (deficiency) } \\
\text { of the MSTN gene in } \\
\text { SCNT-derived progeny }\end{array}$ & $\begin{array}{l}\text { - Expression of myofiber } \\
\text { hyperplasia and hypertrophy in GE } \\
\text { muscular system of homozygous } \\
\left(M S T N^{-/}\right) \text {transgenic cloned offspring }\end{array}$ & [53] \\
\hline & \multirow{2}{*}{$\begin{array}{l}\text { TALEN-mediated } \\
\text { gene editing }\end{array}$} & Electroporation & $\begin{array}{l}\text { - Monoallelically knocking out } \\
\text { the MSTN gene } \\
\text { - Biallelically knocking out the } \\
\text { MSTN gene in } \\
\text { SCNT-derived progeny }\end{array}$ & $\begin{array}{l}\text { - Triggering hyperplasia and } \\
\text { hypertrophy of skeletal myocytes in the } \\
\text { GE muscular system of: } \\
\text { - } \quad \text { either heterozygous }\left(\mathrm{MSTN}^{+/-}\right) \\
\text {transgenic cloned offspring } \\
\text { or their homozygous } \\
\left(\mathrm{MSTN}^{-/-}\right) \text {counterparts }\end{array}$ & [54] \\
\hline & & Electroporation & $\begin{array}{l}\text { - Monoallelic knockout of the } \\
\text { MSTN gene }\left(M S T N^{+/-}\right) \text {in NDCs } \\
\text { - Biallelic knockout of the MSTN } \\
\text { gene }\left(M_{S T N^{-l-}}\right) \text { in NDCs }\end{array}$ & $\begin{array}{l}\text { - Onset of the mono- or biallelically } \\
\text { transcriptionally silencing MSTN gene } \\
\text { in isozygous GE NDCs } \\
\text { - Failure in the generation of GE cloned } \\
\text { progeny exhibiting phenotypes } \\
\text { determined by MSTN mono- or } \\
\text { biallelic deletion }\end{array}$ & [52] \\
\hline
\end{tabular}

The first transgenic cloned kids were generated from the nuclear-transferred embryos reconstructed with caprine somatic cells that had been previously transfected in vitro with relatively simple gene constructs. These gene constructs contained no genomic sequences of the regions encoding structural transgenes, but were composed of the exon segments of genes encoding selectable marker proteins, e.g., PGKneo fusion genes. The aforementioned fusion genes are comprised of murine phosphoglycerate kinase (PGK) promoters and neomycin phosphotransferase (neo) genes. The neo gene determines resistance to selective aminoglycoside antibiotic designated as geneticin disulphate (G418 sulphate). In the study 
by Zou et al. [19], in vitro cultured fetal fibroblasts provided a source of transgenic NDCs for SCNT-based cloning in goats. The transgenic NDCs were created by their transfection with a gene construct that only contained the neo gene. The above-mentioned study resulted in the production of five genetically modified kids. In turn, Keefer et al. [17] and Baldassarre et al. [27,46] used the in vitro lipofection approach to transfect fetal fibroblasts with a more complex plasmid gene construct (CEeGFP). The CEeGFP-fusion gene was composed of: (1) the enhanced green fluorescent protein (eGFP)-reporter gene driven by the human elongation factor- $1 \alpha$ promoter and cytomegalovirus enhancer and (2) the neo gene under the control of the simian virus-40 (SV-40) promoter. Following the transfer of genetically transformed cloned embryos into the reproductive tracts of recipient surrogates, one cloned doe showing the expression of the eGFP-reporter transgene was produced.

Transgenic animals with the high transcriptional activity profiles (diagnosed in vivo) of a xenogeneic gene may be subsequently multiplied by somatic cell cloning. This is particularly justified when biopharmaceuticals stemming from these animals may find widespread application in the treatment of patients suffering from various single-gene heritable disorders. When transgenic biopharmaceuticals obtain certification for application in humans, somatic cell cloning of genetically modified specimens will allow, at least in theory, for the maintenance of homogeneity of the drugs extracted from natural secretions and excretions (milk, urine) of the successive generations of cloned animals. This technology was successfully used by the American biotechnology company GTC Biotherapeutics (formerly Genzyme Transgenics Corporation), which generated transgenic goats exhibiting monoallelic expression of recombinant human antithrombin III gene $(r h A T)$ in their mammary glands (udders). The production of transgenic cloned goats was based on the use of a standard intrapronuclear microinjection into the zygotes of cDNA constructs containing the goat $\beta$-casein gene promoter. In the performed experiments, genetically modified fibroblast cell lines were established from fetuses obtained by mating nontransgenic does with a genetically modified founder buck. This buck displayed transcriptional activity of the $r h A T$ gene that was directed into the mammary gland (udder). Clonal lines of transgenic fetal fibroblast cells served as a source of nuclear donors in the somatic cell cloning procedure, which resulted in a total of eight genetically engineered SCNT-derived female kids [16,45]. The findings of Cheng et al. [28] represent another example of applying the somatic cell cloning technique for multiplying populations of genetically transformed specimens. In this case, enucleated oocytes were reconstructed by SCNT with the use of in vitro cultured fibroblast cell lines collected from dermal tissue explants of a transgenic goat displaying ubiquitous expression of recombinant human erythropoietin (rhEPO). After surgical transfer of the cloned embryos into the reproductive tracts of hormonally synchronized recipient does, two genetically modified kids were born. The SCNT-derived offspring were characterized by mammary gland-specific expression of xenogeneic rhEPO protein.

\section{Transgenic Cloned Goats as Bioreactors That Produce Recombinant Human Therapeutic Proteins}

The nuclear transfer of in vitro-transfected somatic cells increases the probability of producing nonmosaic transgenic offspring, which have an exogenous gene construct incorporated into the primordial germ cell line. Such specimens, which are identified as nonchimeric with regard to the genetic transformation of gametogenic and somatic cells, retain their full capacity to transmit phenotypically and molecularly diagnosed transgene expression to the secretory epithelial cells (lactocytes) in the mammary glands of the next generation of kids $[49,55,56]$. An outstanding example is found in the findings of Baguisi et al. [45]. High-level expression of the rhAT gene detected in the udder lactogenic cells of three cloned does, which were produced from SCNT embryos reconstructed with transgenic fetal fibroblasts, was also reflected in the very high phenotypic value of this genetically modified trait in the milk samples. Over a 33-day lactation induced at 2 months of age, the milk yield of these genetically engineered does reached approximately $160 \mathrm{~mL}$. Additionally, the rhAT concentration in the collected milk was maintained at a level 
of as much as $5.8 \mathrm{~g} / \mathrm{L}(20.5 \mathrm{U} / \mathrm{mL}$ was observed for the enzymatic activity of purified biopharmaceutical) at day 5 and $3.7 \mathrm{~g} / \mathrm{L}(14.6 \mathrm{U} / \mathrm{mL}$ for the biocatalytic activity) by day 9 of lactation. At such high concentrations of recombinant therapeutic proteins in milk, large-sized herds of transgenic goats could easily yield $300 \mathrm{~kg}$ of extracted (purified) biopharmaceutical product per year. Combining somatic cell cloning technology with hormonal induction of early lactation in prepubertal transgenic does will shorten the time needed to obtain the transgene expression product by as much as 8 to 9 months from the time of cell line transfection to the secretion of the genetically engineered protein biopreparation into milk $[20,45]$. On the one hand, the volume of these retrieved milk samples is sufficient for estimating the recombinant protein yield. On the other hand, taking into account even a relatively low quantitative profile of translational activity identified for transgene-transcribed mRNA (as measured by milligram quantities of therapeutic protein per $1 \mathrm{~mL}$ of milk), this amount of milk can be used for multiple clinical tests of the pharmacokinetic, hormonal, and enzymatic activity of the produced biopharmaceuticals.

Special consideration should be given to the broad international commercialization of the first biopharmaceutical in 2006-2009, designated as ATryn ${ }^{\circledR}$, by GTC Biotherapeutics. The basic active biochemical component of this pharmacological biopreparation is rhAT, which was recovered from the milk synthesized and secreted by the udders of transgenic cloned specimens of a large livestock species, the domestic goat $[47,57,58]$. This is a milestone in the practical, commercial-scale implementation of the first biopharmaceutical product of modern mammalian reproductive biotechnology based on embryonic genome engineering technologies such as transgenesis and somatic cell cloning of farm animals. It is worth pointing out here that ATryn ${ }^{\circledR}$ is the world's first drug to be provided by mammary gland-based bioreactors of genetically engineered cloned goats that exhibit highly efficient and organ-specific mono- or biallelic expression of the $r h A T$ transgene. This biopharmaceutical was originally granted a marketing authorization by the European Medicines Agency (EMA) in 2006 for use in the biopharmaceutical and medical sector of the European Union, followed by certification from the United States Food and Drug Administration (FDA or USFDA) in 2009 for marketing in the biopharmaceutical and biomedical sector in the USA and Canada $[1,59]$. At this stage, ATryn ${ }^{\circledR}$ is widely used in biomedical programs/therapeutic platforms for the treatment of hereditary AT deficiency in hospitalized medical patients $[60,61]$.

Another example of the practical application of the mammary glands of genetically transformed cloned goats as bioreactors to synthesize human therapeutic proteins or socalled humanized milk is found in the study by Zhu et al. [21]. This investigation was aimed at ameliorating allergic reactions and inflammatory responses to $\beta$-lactoglobulin (BLG) protein (Table 1). As a major whey protein with potential allergenic effect, BLG occurs in the milk of all even-toed mammals (Artiodactyla), including the domestic goat. It has no allergenic properties in human milk. The presence of this protein in caprine milk considerably limits, to a high degree, the consumption of this lactogenesis-derived product despite its high nutritive value and health-promoting benefits. Using conventional homologous recombination, the above-mentioned investigators were the first to functionally inactivate a single copy of the $B L G$ gene, either through $B L G$ gene knockout or through $h L A$ (human $\alpha$-lactalbumin) gene knock-in into the nuclear genome of in vitro cultured fetal fibroblast cells. These cells subsequently provided a source of nuclear donors for reconstructing enucleated doe oocytes in the somatic cell cloning procedure. The ultimate outcome of this research was the birth of three SCNT-derived kids, among which mono-allelic knockout of the targeted BLG gene was confirmed in two specimens (Table 1) [21].

In turn, Yuan et al. [22] used the strategy of somatic cell cloning to generate transgenic goats whose udders were bioreactors that synthesized humanized milk containing pharmaceutical or nutraceutical immune glycoprotein, known as recombinant human lactoferrin (hLF). Genetically transformed fetal fibroblasts provided the source of nuclear donor cells for the reconstruction of enucleated oocytes by somatic cell cloning. The genome of nuclear donor cells had been previously edited by inserting $h L F$ cDNA into the BLG locus, i.e., by 
replacing the $B L G$ gene with the $h L F$ gene. Editing the nuclear genome of fetal fibroblast cells had been mediated by transcription activator-like effector nucleases (TALENs). The efficiency of the targeted mutagenesis observed for the BLG gene oscillated at the level of approximately $10 \%$. The results of investigations by Yuan et al. [22] confirmed that the combination of TALEN-based genome editing with the SCNT strategy gave rise to biallelic inactivation of the $B L G$ gene through the knock-in of $h L F$ exons into the genomic DNA of cloned goats whose mammary glands were targeted by programmed genetic transformation to produce recombinant hLF (Table 1). Transgenically encoded qualitative and quantitative modification of the biochemical composition of caprine milk that subsequently brought about the production of humanized milk in the udders of SCNT-derived goats appears to ameliorate its allergenicity. Diminishing the capability of the milk provided by genetically engineered bioreactors to trigger acute allergic reactions in humans is simultaneously reflected in enriching the goat milk with the valuable multipotent protein designated as LF. This immune glycoprotein, apart from physiologically regulating the dynamic homeostasis of the metabolism of iron cations, is characterized by several other desirable immunotherapeutic properties, including antimicrobial (antibacterial, mycostatic, and antiviral), immunomodulatory, anti-inflammatory, and anticancer abilities (Table 1) $[22,24,56]$.

It is also noteworthy that Zhang et al. [50] reported the effective integration of the recombinant $h L F$ gene with the xenogeneic host genome as a result of genetically transforming the caprine fetal fibroblast cells under in vitro culture conditions. The genetically transformed fetal fibroblasts were subsequently used to generate transgenic kids (does) with the $h L F$ gene in ear skin tissue samples by somatic cell cloning (Table 1). Out of the six transgenic cloned kids produced, three does died during the perinatal period due to severe bronchopulmonary dysplasia in underdeveloped lungs and acute hypoxemic respiratory failure. The epigenetic analysis of tissue explants collected postmortem from the lungs of perished transgenic does revealed hypermethylation of CpG islands/dinucleotides within the DMR/ICR domain of the gene encoding insulin-like growth factor 2 receptor (IGF2R). For that reason, the maternal allele of the IGF2R gene was found to be transcriptionally overactive/upregulated due to enhanced methylation of cytosine residues in the DMR/ICR-associated intron sequence, while its paternal counterpart was shown to be transcriptionally silenced due to the occurrence of parent-of-origin and allele-specific methylation imprint. As a result, the overexpression of mRNA transcribed by the maternal allele of the IGF2R gene that had undergone aberrant genomic imprinting was identified in the cell samples of postmortem isolated lung tissue explants stemming from the cloned kids [50].

In summary, imprinted genes are an important epigenomic regulator of anatomohistological growth and development and physiological maturation of the lungs. In turn, aberrant or incomplete reprogramming of the epigenetically determined transcriptional activity of DNA, which underlies abnormal (i.e., increased) methylation of cytosine moieties within DMR/ICR-related intron sequences of the imprinted maternal allele of the IGF2R gene, determines the monoallelic overexpression of this gene exprimed from the maternal genome in the lungs of cloned fetuses. The latter appears to be one of the main lethal factors positively correlated with etiopathogenesis of lung hypoplasia and acute pulmonary insufficiency in neonatal transgenic cloned kids [50].

\section{Transgenic Cloned Goats as a Source of Valuable Meat for Humans}

Attempts to create and multiply transgenic cloned goats may provide a research basis for the SCNT-mediated generation of genetically engineered specimens (bucks and does) that exhibit genotypic and phenotypic modifications related to increased carcass meatiness and decreased intramuscular fatness. These animals could serve as a valuable research model for expanding our knowledge of the importance of myostatin, e.g., in the context of the quality and taste of the meat from individuals displaying superior gains in muscle tissue and myofiber size. Myostatin, encoded by the MSTN gene, is a hormonal inhibitory 
polypeptide that inhibits/downregulates the growth, differentiation, maturation, and development of skeletal muscles in mammals. Research shows that functional inactivation of the MSTN gene using gene targeting (targeted mutagenesis) or genome editing techniques contributes to increase skeletal muscle mass while diminishing the content of intramuscular adipose tissue and reducing genetically determined or diet-induced obesity. This has the beneficial effects of increased meat yield, fattening performance, and dressing percentage in genetically modified males and females generated by SCNT-based cloning. These effects are evoked by cellular hyperplasia (proliferation) and hypertrophy (enlargement) of striated muscle tissue (Table 1). The hyperplasia and hypertrophy of striated muscle cells (i.e., skeletal sarcocytes known as syncytial myocytes) are synergistically triggered as a result of the following:

- Expediting differentiation of the predominant multipotent muscle stem cells (i.e., satellite cells) and their myogenic progenitor cell derivatives into primary myoblasts;

- Accelerating the proliferative growth of mononucleated myoblasts;

- Facilitating cyto- and histophysiological maturation of genetically engineered skeletal muscle tissue by syncytial fusion of myoblasts and their conversion (transformation) into myotubes and the resultant multinucleated myofibers;

- Enlargement of muscle fibers;

- Extension of myofiber lengths and individual sarcomere lengths in whole muscle fibers;

- Increase in both myofibrillar volume and myofiber number [25,62,63].

It is beyond any doubt that SCNT-derived goats that are characterized by MSTN gene silencing (Table 1) [25] represent a powerful, reliable, and feasible tool for investigations targeted at nutritional physiology, food technology, dietetics, nutrigenomics, nutriepigenomics, nutritranscriptomics, nutriproteomics, and human nutrition metabolomics and metabonomics. Myostatin gene knockout (MSTN-KO) in goats (Table 1) $[25,62,64]$ and sheep $[63,65]$ was investigated in several research centers. However, as a result of the low efficacy of homologous recombination (HR)-mediated targeted mutagenesis, shorthairpin RNA-mediated gene targeting, and zinc-finger nuclease (ZFN)-mediated genome editing, only a few studies resulted in successful MSTN gene knockdown in ex vivo expanded caprine juvenile cutaneous fibroblasts [25], ovine fetal myoblasts [63], or ovine fetal cutaneous fibroblasts [65].

In recent years, other noteworthy solutions have been applied to genome editing and have been subsequently adapted to ARTs. These were then applied in combination to cloning goats using SCNT. These solutions are aimed at strategies based on the use of TALENs or the clustered regularly interspaced short palindromic repeat/CRISPR-associated endonuclease type 9 (CRISPR/Cas9)-assisted system. The progress achieved in developing and optimizing the techniques of targeted knockout of specific gene loci is promising. Therefore, these techniques are increasingly utilized for precise genome editing, allowing for the genome of mammals, including the domestic goat, to be modified with relative ease [66-71]. Ni et al. [53] were the first to demonstrate that CRISPR/Cas9-mediated genome editing can induce accurate mono- or biallelic mutations in the MSTN gene of caprine fetal fibroblast cells. The clonal lines of these NDCs that exhibit biallelic MSTN-KO were used in a SCNT procedure, resulting in three live-born cloned kids, all of which carried a biallelic mutation in the form of double inactivation of the MSTN gene's loci (Table 1).

In turn, Yu et al. [54] showed that TALEN-based genetic transformation leads to the successful inhibition of MSTN gene expression in gene-edited cloned goats (Table 1). Moreover, the outcome of both TALEN- and CRISPR/Cas9-mediated systems that were applied to edit the nuclear genome of SCNT-derived Alpas breed cashmere goats (Table 1) was evaluated by Zhang et al. [52]. The efficiency of triggering MSTN-KO was compared at many levels of pre- and postimplantation development of transgenic cloned embryos. The rates of both electro-transfecting/electroporating the somatic cells and cutting exon 1 within the MSTN gene were found to be higher for the CRISPR/Cas9-assisted strategy of genome 
editing than for its TALEN-mediated counterpart. Nevertheless, the genome-wide offtarget effects were shown to be more frequent for the CRISPR/Cas9-mediated system than for the TALEN-mediated system. Furthermore, for CRISPR/Cas9-based genome editing, the incidence of effectively inducing targeted biallelic mutagenesis of the MSTN gene increased over eight times as compared to TALEN-based genome editing. In turn, caprine SCNT embryos that had been reconstructed with TALEN-mediated transgenic NDCs reached the 8-blastomere stage more quickly and their cleavage activity was significantly higher as compared to SCNT embryos derived from CRISPR/Cas9-mediated gene-edited NDCs. However, cloned kids were produced, following the surgical transfer of SCNT embryos into recipient does, that stemmed from NDCs that were genetically modified only using the CRISPR/Cas9-assisted technique (Table 1). This ultimately suggests that the high yield of generating targeted modifications of the MSTN gene (MSTN-KO) was achieved using CRISPR/Cas9-mediated genome editing [52].

To summarize, the study by Zhang et al. [52] proved that, although the TALENdependent genome transformation strategy has a certain advantage over the CRISPR/Cas9dependent system, the latter offers significant benefits related to the precision programmed editing of the genes (Table 1). This makes this system a powerful and high-performance genetic engineering tool for livestock breeding practice and, in particular, in the fields of agri-food biotechnology and human food technology (nutritechnology) based on a meat diet [52,68-71].

\section{Conclusions and Future Goals}

Although the efficiency of somatic cell cloning in goats remains relatively low, further studies are necessary because modern ART has important implications in the fields of goat breeding, the transgenics of this mammalian species, agri-food biotechnology, biomedicine, and biopharmacy.

An increase in the efficiency of somatic cell cloning techniques in the domestic goat can be brought about by further intensive research into improving both developmental competence and the parameters related to the molecular and epigenetic quality of SCNTderived embryos. The latter can be achieved by efforts aimed at using nonselective or selective inhibitors of DNMTs and HDACs, which would in turn lead to enhancements in the reprogrammability of the epigenetic memory profile within genomic DNA of NDCs, nuclear-transferred oocytes, and the corresponding caprine cloned embryos. This is a sine qua non condition for the practical use of SCNT-based cloning, and thus for the production of genetically transformed goats for the purposes of human nutrition technology based on a meat diet. The main focus of the aforementioned efforts is the successful SCNT-mediated creation and multiplication of transgenic does and bucks with enhanced meat yields due to cellular hyperplasia and hypertrophy within skeletal muscle tissue. This is also a basic requirement for the effective propagation of genetically engineered or genome-edited does for the biopharmaceutical and nutraceutical industry. An ideal example of this is the generation of transgenic goats whose udders serve as bioreactors for recombinant human therapeutic proteins or biochemically humanized milk.

Author Contributions: Conceptualization, M.S. (Maria Skrzyszowska) and M.S. (Marcin Samiec); Writing — original draft, M.S. (Maria Skrzyszowska) and M.S. (Marcin Samiec); Writing—review and editing, M.S. (Marcin Samiec); Supervision and funding acquisition, M.S. (Marcin Samiec); Tabular and graphic documentation, M.S. (Marcin Samiec) and M.S. (Maria Skrzyszowska). All authors have read and agreed to the published version of the manuscript.

Funding: This work was financially supported by the Ministry of Education and Science in Poland as a statutory activity No. 04-19-05-00.

Institutional Review Board Statement: Not applicable.

Informed Consent Statement: Not applicable.

Data Availability Statement: Not applicable. 
Conflicts of Interest: The authors declare no conflict of interest.

\section{Abbreviations}

ART Assisted reproductive technology

BLG $\quad \beta$-lactoglobulin

Cas9 CRISPR-associated endonuclease type 9

$\mathrm{Cdx} 2$ A product transcribed from proto-oncogene/oncogene encoding caudal-type homeobox protein 2 that represents the family of intestinal epithelium/ adenocarcinoma-specific and DNA-binding homeodomain transcription factors inevitable in intestinal organogenesis

c-Myc Avian myelocytomatosis viral oncogene homolog encoding a DNA-binding proto-oncogenic/oncogenic transcription factor

CpG 5' $\quad 5^{\prime}$-Cytidine- $3^{\prime}$-monophopshate-5'-guanosine- $3^{\prime}$

CRISPR Clustered regularly interspaced short palindromic repeat

DMR Differentially methylated region

DNMT DNA methyltransferase

eGFP Enhanced green fluorescent protein

GE Genome-edited

GEM Genetically engineered milk

HAT Histone acetyltransferase

HDAC Histone deacetylase

HMT Histone methyltransferase

hLA Human $\alpha$-lactalbumin

hLF Human lactoferrin

HR Homologous recombination

ICM Inner cell mass

ICR Imprinting control region

ICSI Intracytoplasmic sperm injection

IGF2R Insulin-like growth factor 2 receptor

Klf4 Krüppel-like factor 4 (also called gut-enriched Krüppel-like factor or GKLF); an evolutionarily conserved zinc finger-containing transcription factor that regulates diverse cellular processes such as cell growth, proliferation, differentiation, apoptosis, and somatic cell reprogramming

5-mC 5-Methylcytosine

MSTN Myostatin

MSTN-KO Myostatin gene knockout

Nanog Homeobox-containing transcription factor whose name stems from the Celtic/Irish mythical word Tír na nÓg (i.e., Tir Na Nog; The Land of the Ever-Young)

NDC Nuclear donor cell

Oct3/4 Octamer-binding transcription factor 3/4 (also designated as POU5F1); a member of the family of POU (Pit-Oct-Unc)-domain and homeodomain transcription factors

2-PCPA Trans-2-phenylcyclopropylamine; Tranylcypromine

PGKneo Neomycin phosphoglycerol kinase; Neomycin glycerol phosphotransferase

Rex1 Reduced expression gene 1 encoding a DNA-binding transcription factor known as reduced expression protein 1 or zinc finger protein 42 homolog

rhAT Recombinant human antithrombin III

rhEPO Recombinant human erythropoietin

SCNT Somatic cell nuclear transfer

Sox2 Sex-determining region Y (SRY)-box 2; a member of the high mobility group (HMG)-box family of DNA-binding transcription factors

SV-40 Simian virus-40

TALEN Transcription activator-like effector nuclease

TET3 Ten-eleven translocation 3 protein; TET 5-methylcytosine dioxygenase 3

Xist $\quad X$-inactive specific transcript

ZFN Zinc-finger nuclease 


\section{References}

1. Samiec, M.; Skrzyszowska, M. Transgenic mammalian species, generated by somatic cell cloning, in biomedicine, biopharmaceutical industry and human nutrition/dietetics—Recent achievements. Pol. J. Vet. Sci. 2011, 14, 317-328. [CrossRef]

2. Samiec, M.; Skrzyszowska, M. The possibilities of practical application of transgenic mammalian species generated by somatic cell cloning in pharmacology, veterinary medicine and xenotransplantology. Pol. J. Vet. Sci. 2011, 14, 329-340. [CrossRef]

3. Hall, V.; Hinrichs, K.; Lazzari, G.; Betts, D.H.; Hyttel, P. Early embryonic development, assisted reproductive technologies, and pluripotent stem cell biology in domestic mammals. Vet. J. 2013, 197, 128-142. [CrossRef]

4. Skrzyszowska, M.; Samiec, M. Generation of monogenetic cattle by different techniques of embryonic cell and somatic cell cloning-Their application to biotechnological, agricultural, nutritional, biomedical and transgenic research-A review. Ann. Anim. Sci. 2021, 21, 1-15.

5. $\quad$ Martins, L.T.; Neto, S.G.; Tavares, K.C.; Calderón, C.E.; Aguiar, L.H.; Lazzarotto, C.R.; Ongaratto, F.L.; Rodrigues, V.H.; Carneiro Ide, S.; Rossetto, R.; et al. Developmental outcome and related abnormalities in goats: Comparison between somatic cell nuclear transfer- and in vivo-derived concepti during pregnancy through term. Cell. Reprogram. 2016, 18, 264-279. [CrossRef] [PubMed]

6. Samiec, M.; Skrzyszowska, M. Can reprogramming of overall epigenetic memory and specific parental genomic imprinting memory within donor cell-inherited nuclear genome be a major hindrance for the somatic cell cloning of mammals?-A review. Ann. Anim. Sci. 2018, 18, 623-638. [CrossRef]

7. Samiec, M.; Skrzyszowska, M. Intrinsic and extrinsic molecular determinants or modulators for epigenetic remodeling and reprogramming of somatic cell-derived genome in mammalian nuclear-transferred oocytes and resultant embryos. Pol. J. Vet. Sci. 2018, 21, 217-227. [PubMed]

8. Yang, M.; Perisse, I.; Fan, Z.; Regouski, M.; Meyer-Ficca, M.; Polejaeva, I.A. Increased pregnancy losses following serial somatic cell nuclear transfer in goats. Reprod. Fertil. Dev. 2018, 30, 1443-1453. [CrossRef] [PubMed]

9. Deng, M.; Liu, Z.; Chen, B.; Wan, Y.; Yang, H.; Zhang, Y.; Cai, Y.; Zhou, J.; Wang, F. Aberrant DNA and histone methylation during zygotic genome activation in goat cloned embryos. Theriogenology 2020, 148, 27-36. [CrossRef] [PubMed]

10. Deng, M.; Zhang, G.; Cai, Y.; Liu, Z.; Zhang, Y.; Meng, F.; Wang, F.; Wan, Y. DNA methylation dynamics during zygotic genome activation in goat. Theriogenology 2020, 156, 144-154. [CrossRef] [PubMed]

11. Iager, A.E.; Ragina, N.P.; Ross, P.J.; Beyhan, Z.; Cunniff, K.; Rodriguez, R.M.; Cibelli, J.B. Trichostatin A improves histone acetylation in bovine somatic cell nuclear transfer early embryos. Cloning Stem Cells 2008, 10, 371-379. [CrossRef]

12. Mao, T.; Han, C.; Deng, R.; Wei, B.; Meng, P.; Luo, Y.; Zhang, Y. Treating donor cells with 2-PCPA corrects aberrant histone H3K4 dimethylation and improves cloned goat embryo development. Syst. Biol. Reprod. Med. 2018, 64, 174-182. [CrossRef]

13. Samiec, M.; Romanek, J.; Lipiński, D.; Opiela, J. Expression of pluripotency-related genes is highly dependent on trichostatin Aassisted epigenomic modulation of porcine mesenchymal stem cells analysed for apoptosis and subsequently used for generating cloned embryos. Anim. Sci. J. 2019, 90, 1127-1141. [CrossRef]

14. Skrzyszowska, M.; Samiec, M. Enhancement of in vitro developmental outcome of cloned goat embryos after epigenetic modulation of somatic cell-inherited nuclear genome with trichostatin A. Ann. Anim. Sci. 2020, 20, 97-108. [CrossRef]

15. Wiater, J.; Samiec, M.; Skrzyszowska, M.; Lipiński, D. Trichostatin A-assisted epigenomic modulation affects the expression profiles of not only recombinant human $\alpha 1$,2-fucosyltransferase and $\alpha$-galactosidase A enzymes but also Gal $\alpha 1 \rightarrow 3 \mathrm{Gal}$ epitopes in porcine bi-transgenic adult cutaneous fibroblast cells. Int. J. Mol. Sci. 2021, 22, 1386. [CrossRef]

16. Reggio, B.C.; James, A.N.; Green, H.L.; Gavin, W.G.; Behboodi, E.; Echelard, Y.; Godke, R.A. Cloned transgenic offspring resulting from somatic cell nuclear transfer in the goat: Oocytes derived from both follicle-stimulating hormone-stimulated and nonstimulated abattoir-derived ovaries. Biol. Reprod. 2001, 65, 1528-1533. [CrossRef]

17. Keefer, C.L.; Baldassarre, H.; Keyston, R.; Wang, B.; Bhatia, B.; Bilodeau, A.S.; Zhou, J.F.; Leduc, M.; Downey, B.R.; Lazaris, A.; et al. Generation of dwarf goat (Capra hircus) clones following nuclear transfer with transfected and nontransfected fetal fibroblasts and in vitro-matured oocytes. Biol. Reprod. 2001, 64, 849-856. [CrossRef]

18. Keefer, C.L.; Keyston, R.; Lazaris, A.; Bhatia, B.; Begin, I.; Bilodeau, A.S.; Zhou, F.J.; Kafidi, N.; Wang, B.; Baldassarre, H.; et al. Production of cloned goats after nuclear transfer using adult somatic cells. Biol. Reprod. 2002, 66, 199-203. [CrossRef]

19. Zou, X.; Wang, Y.; Cheng, Y.; Yang, Y.; Ju, H.; Tang, H.; Shen, Y.; Mu, Z.; Xu, S.; Du, M. Generation of cloned goats (Capra hircus) from transfected foetal fibroblast cells, the effect of donor cell cycle. Mol. Reprod. Dev. 2002, 61, 164-172. [CrossRef]

20. Baldassarre, H.; Wang, B.; Pierson, J.; Neveu, N.; Lapointe, J.; Cote, F.; Kafidi, N.; Keefer, C.L.; Lazaris, A.; Karatzas, C.N. Prepubertal propagation of transgenic cloned goats by laparoscopic ovum pick-up and in vitro embryo production. Cloning Stem Cells 2004, 6, 25-29. [CrossRef]

21. Zhu, H.; Hu, L.; Liu, J.; Chen, H.; Cui, C.; Song, Y.; Jin, Y.; Zhang, Y. Generation of $\beta$-lactoglobulin-modified transgenic goats by homologous recombination. FEBS J. 2016, 283, 4600-4613. [CrossRef]

22. Yuan, Y.G.; Song, S.Z.; Zhu, M.M.; He, Z.Y.; Lu, R.; Zhang, T.; Mi, F.; Wang, J.Y.; Cheng, Y. Human lactoferrin efficiently targeted into caprine beta-lactoglobulin locus with transcription activator-like effector nucleases. Asian Australas. J. Anim. Sci. 2017, 30, 1175-1182. [CrossRef]

23. Behboodi, E.; Memili, E.; Melican, D.T.; Destrempes, M.M.; Overton, S.A.; Williams, J.L.; Flanagan, P.A.; Butler, R.E.; Liem, H.; Chen, L.H.; et al. Viable transgenic goats derived from skin cells. Transgenic Res. 2004, 13, 215-224. [CrossRef] [PubMed] 
24. Wan, Y.J.; Zhang, Y.L.; Zhou, Z.R.; Jia, R.X.; Li, M.; Song, H.; Wang, Z.Y.; Wang, L.Z.; Zhang, G.M.; You, J.H.; et al. Efficiency of donor cell preparation and recipient oocyte source for production of transgenic cloned dairy goats harboring human lactoferrin. Theriogenology 2012, 78, 583-592. [CrossRef] [PubMed]

25. Zhou, Z.R.; Zhong, B.S.; Jia, R.X.; Wan, Y.J.; Zhang, Y.L.; Fan, Y.X.; Wang, L.Z.; You, J.H.; Wang, Z.Y.; Wang, F. Production of myostatin-targeted goat by nuclear transfer from cultured adult somatic cells. Theriogenology 2013, 79, 225-233. [CrossRef] [PubMed]

26. Kumar, D.; Sarkhel, B.C. Differential expression pattern of key regulatory developmental genes in pre-implant zona free cloned vs in vitro fertilized goat embryos. Gene Expr. Patterns 2017, 25, 118-123. [CrossRef] [PubMed]

27. Baldassarre, H.; Wang, B.; Kafidi, N.; Keefer, C.L.; Lazaris, A.; Karatzas, C.N. Advances in the production and propagation of transgenic goats using laparoscopic ovum pick-up and in vitro embryo production technologies. Theriogenology 2002, 57, 275-284. [CrossRef]

28. Cheng, Y.; Wang, Y.G.; Luo, J.P.; Shen, Y.; Yang, Y.F.; Ju, H.M.; Zou, X.G.; Xu, S.F.; Lao, W.D.; Du, M. Cloned goats produced from the somatic cells of an adult transgenic goat. Sheng Wu Gong Cheng Xue Bao (Chin. J. Biotechnol.) 2002, 18, 79-83. (In Chinese)

29. Ohkoshi, K.; Takahashi, S.; Koyama, S.; Akagi, S.; Adachi, N.; Furusawa, T.; Fujimoto, J.; Takeda, K.; Kubo, M.; Izaike, Y.; et al. In vitro oocyte culture and somatic cell nuclear transfer used to produce a live-born cloned goat. Cloning Stem Cells 2003, 5, 109-115. [CrossRef]

30. Deng, M.; Liu, Z.; Ren, C.; An, S.; Wan, Y.; Wang, F. Highly methylated Xist in SCNT embryos was retained in deceased cloned female goats. Reprod. Fertil. Dev. 2019, 31, 855-866. [CrossRef]

31. Wang, F.; Kou, Z.; Zhang, Y.; Gao, S. Dynamic reprogramming of histone acetylation and methylation in the first cell cycle of cloned mouse embryos. Biol. Reprod. 2007, 77, 1007-1016. [CrossRef]

32. Deng, M.; Ren, C.; Liu, Z.; Zhang, G.; Wang, F.; Wan, Y. Epigenetic status of H19-Igf2 imprinted genes and loss of 5hydroxymethylcytosine in the brain of cloned goats. Cell. Reprogram. 2017, 19, 199-207. [CrossRef]

33. Han, C.; Deng, R.; Mao, T.; Luo, Y.; Wei, B.; Meng, P.; Zhao, L.; Zhang, Q.; Quan, F.; Liu, J.; et al. Overexpression of Tet3 in donor cells enhances goat somatic cell nuclear transfer efficiency. FEBS J. 2018, 285, 2708-2723. [CrossRef]

34. Yang, F.; Hao, R.; Kessler, B.; Brem, G.; Wolf, E.; Zakhartchenko, V. Rabbit somatic cell cloning: Effects of donor cell type, histone acetylation status and chimeric embryo complementation. Reproduction 2007, 133, 219-230. [CrossRef]

35. Yamanaka, K.; Sugimura, S.; Wakai, T.; Kawahara, M.; Sato, E. Acetylation level of histone H3 in early embryonic stages affects subsequent development of miniature pig somatic cell nuclear transfer embryos. J. Reprod. Dev. 2009, 55, 638-644. [CrossRef]

36. Wan, Y.; Deng, M.; Zhang, G.; Ren, C.; Zhang, H.; Zhang, Y.; Wang, L.; Wang, F. Abnormal expression of DNA methyltransferases and genomic imprinting in cloned goat fibroblasts. Cell Biol. Int. 2016, 40, 74-82. [CrossRef]

37. Xiong, X.; Lan, D.; Li, J.; Zhong, J.; Zi, X.; Ma, L.; Wang, Y. Zebularine and scriptaid significantly improve epigenetic reprogramming of yak fibroblasts and cloning efficiency. Cell. Reprogram. 2013, 15, 293-300. [CrossRef]

38. Xiong, X.R.; Li, J.; Fu, M.; Gao, C.; Wang, Y.; Zhong, J.C. Oocyte extract improves epigenetic reprogramming of yak fibroblast cells and cloned embryo development. Theriogenology 2013, 79, 462-469. [CrossRef]

39. Zhang, Y.; Li, J.; Villemoes, K.; Pedersen, A.M.; Purup, S.; Vajta, G. An epigenetic modifier results in improved in vitro blastocyst production after somatic cell nuclear transfer. Cloning Stem Cells 2007, 9, 357-363. [CrossRef]

40. Wang, Y.S.; Xiong, X.R.; An, Z.X.; Wang, L.J.; Liu, J.; Quan, F.S.; Hua, S.; Zhang, Y. Production of cloned calves by combination treatment of both donor cells and early cloned embryos with 5-aza-2'-deoxycytidine and trichostatin A. Theriogenology 2011, 75, 819-825. [CrossRef]

41. Dutta, R.; Malakar, D.; Khate, K.; Sahu, S.; Akshey, Y.; Mukesh, M. A comparative study on efficiency of adult fibroblast, putative embryonic stem cell and lymphocyte as donor cells for production of handmade cloned embryos in goat and characterization of putative ntES cells obtained from these embryos. Theriogenology 2011, 76, 851-863. [CrossRef]

42. Gómez, M.C.; Biancardi, M.N.; Jenkins, J.A.; Dumas, C.; Galiguis, J.; Wang, G.; Earle Pope, C. Scriptaid and 5-aza-2'deoxycytidine enhanced expression of pluripotent genes and in vitro developmental competence in interspecies black-footed cat cloned embryos. Reprod. Domest. Anim. 2012, 47, 130-135. [CrossRef] [PubMed]

43. Zhao, J.; Hao, Y.; Ross, J.W.; Spate, L.D.; Walters, E.M.; Samuel, M.S.; Rieke, A.; Murphy, C.N.; Prather, R.S. Histone deacetylase inhibitors improve in vitro and in vivo developmental competence of somatic cell nuclear transfer porcine embryos. Cell. Reprogram. 2010, 12, 75-83. [CrossRef] [PubMed]

44. Kim, Y.J.; Ahn, K.S.; Kim, M.; Shim, H. Comparison of potency between histone deacetylase inhibitors trichostatin A and valproic acid on enhancing in vitro development of porcine somatic cell nuclear transfer embryos. In Vitro Cell. Dev. Biol. Anim. 2011, 47, 283-289. [CrossRef] [PubMed]

45. Baguisi, A.; Behboodi, E.; Melican, D.T.; Pollock, J.S.; Destrempes, M.M.; Cammuso, C.; Williams, J.L.; Nims, S.D.; Porter, C.A.; Midura, P.; et al. Production of goats by somatic cell nuclear transfer. Nat. Biotechnol. 1999, 17, 456-461. [CrossRef]

46. Baldassarre, H.; Keefer, C.; Wang, B.; Lazaris, A.; Karatzas, C.N. Nuclear transfer in goats using in vitro matured oocytes recovered by laparoscopic ovum pick-up. Cloning Stem Cells 2003, 5, 279-285. [CrossRef] [PubMed]

47. An, L.; Yang, L.; Huang, Y.; Cheng, Y.; Du, F. Generating goat mammary gland bioreactors for producing recombinant proteins by gene targeting. Methods Mol. Biol. 2019, 1874, 391-401. [PubMed]

48. Lu, R.; Zhang, T.; Wu, D.; He, Z.; Jiang, L.; Zhou, M.; Cheng, Y. Production of functional human CuZn-SOD and EC-SOD in bitransgenic cloned goat milk. Transgenic Res. 2018, 27, 343-354. [CrossRef] 
49. Gash, K.K.; Yang, M.; Fan, Z.; Regouski, M.; Rutigliano, H.M.; Polejaeva, I.A. Assessment of microchimerism following somatic cell nuclear transfer and natural pregnancies in goats. J. Anim. Sci. 2019, 97, 3786-3794. [CrossRef]

50. Zhang, Y.L.; Zhang, G.M.; Wan, Y.J.; Jia, R.X.; Li, P.Z.; Han, L.; Wang, F.; Huang, M.R. Identification of transgenic cloned dairy goats harboring human lactoferrin and methylation status of the imprinted gene IGF2R in their lungs. Genet. Mol. Res. 2015, 14, 11099-11108. [CrossRef]

51. Meng, L.; Wan, Y.; Sun, Y.; Zhang, Y.; Wang, Z.; Song, Y.; Wang, F. Generation of five human lactoferrin transgenic cloned goats using fibroblast cells and their methylation status of putative differential methylation regions of IGF2R and H19 imprinted genes. PLoS ONE 2013, 8, e77798. [CrossRef]

52. Zhang, J.; Liu, J.; Yang, W.; Cui, M.; Dai, B.; Dong, Y.; Yang, J.; Zhang, X.; Liu, D.; Liang, H.; et al. Comparison of gene editing efficiencies of CRISPR/Cas9 and TALEN for generation of MSTN knock-out cashmere goats. Theriogenology 2019, 132, 1-11. [CrossRef]

53. Ni, W.; Qiao, J.; Hu, S.; Zhao, X.; Regouski, M.; Yang, M.; Polejaeva, I.A.; Chen, C. Efficient gene knockout in goats using CRISPR/Cas9 system. PLoS ONE 2014, 9, e106718. [CrossRef]

54. Yu, B.; Lu, R.; Yuan, Y.; Zhang, T.; Song, S.; Qi, Z.; Shao, B.; Zhu, M.; Mi, F.; Cheng, Y. Efficient TALEN-mediated myostatin gene editing in goats. BMC Dev. Biol. 2016, 16, 26. [CrossRef]

55. Baldassarre, H.; Wang, B.; Kafidi, N.; Gauthier, M.; Neveu, N.; Lapointe, J.; Sneek, L.; Leduc, M.; Duguay, F.; Zhou, J.F.; et al. Production of transgenic goats by pronuclear microinjection of in vitro produced zygotes derived from oocytes recovered by laparoscopy. Theriogenology 2003, 59, 831-839. [CrossRef]

56. Zhang, T.; Yuan, Y.; Lu, R.; Xu, S.; Zhou, M.; Yuan, T.; Lu, Y.; Yan, K.; Cheng, Y. The goat $\beta$-casein/CMV chimeric promoter drives the expression of hLF in transgenic goats produced by cell transgene microinjection. Int. J. Mol. Med. 2019, 44, 2057-2064. [CrossRef]

57. Echelard, Y.; Ziomek, C.A.; Meade, H.M. Production of recombinant therapeutic proteins in the milk of transgenic animals. BioPharm Int. 2006, 19, 36-46.

58. Niemann, H.; Kues, W.A. Transgenic farm animals: An update. Reprod. Fertil. Dev. 2007, 19, 762-770. [CrossRef]

59. Shepelev, M.V.; Kalinichenko, S.V.; Deykin, A.V.; Korobko, I.V. Production of recombinant proteins in the milk of transgenic animals: Current state and prospects. Acta Nat. 2018, 10, 40-47. [CrossRef]

60. Echelard, Y.; Meade, H.M.; Ziomek, C.A. The first biopharmaceutical from transgenic animals: ATryn ${ }^{\circledR}$. In Modern Biopharmaceuticals: Design, Development and Optimization; Knäblein, J., Ed.; WILEY-VCH Verlag GmbH \& Co. KGaA: Weinheim, Germany, 2005; Chapter 11; pp. 995-1020, Print ISBN: 9783527311842, Online ISBN: 9783527620982, ISBN 9783527311842. [CrossRef]

61. Patnaik, M.M.; Moll, S. Inherited antithrombin deficiency: A review. Haemophilia 2008, 14, 1229-1239. [CrossRef]

62. Wang, X.; Yu, H.; Lei, A.; Zhou, J.; Zeng, W.; Zhu, H.; Dong, Z.; Niu, Y.; Shi, B.; Cai, B.; et al. Generation of gene-modified goats targeting MSTN and FGF5 via zygote injection of CRISPR/Cas9 system. Sci. Rep. 2015, 5, 13878. [CrossRef] [PubMed]

63. Liu, C.; Li, W.; Zhang, X.; Zhang, N.; He, S.; Huang, J.; Ge, Y.; Liu, M. Knockdown of endogenous myostatin promotes sheep myoblast proliferation. In Vitro Cell. Dev. Biol. Anim. 2014, 50, 94-102. [CrossRef] [PubMed]

64. Petersen, B.; Niemann, H. Molecular scissors and their application in genetically modified farm animals. Transgenic Res. 2015, 24, 381-396. [CrossRef] [PubMed]

65. Zhang, C.; Wang, L.; Ren, G.; Li, Z.; Ren, C.; Zhang, T.; Xu, K.; Zhang, Z. Targeted disruption of the sheep MSTN gene by engineered zinc-finger nucleases. Mol. Biol. Rep. 2014, 41, 209-215. [CrossRef]

66. Miller, J.C.; Tan, S.; Qiao, G.; Barlow, K.A.; Wang, J.; Xia, D.F.; Meng, X.; Paschon, D.E.; Leung, E.; Hinkley, S.J.; et al. A TALE nuclease architecture for efficient genome editing. Nat. Biotechnol. 2011, 29, 143-148. [CrossRef]

67. Frock, R.L.; Hu, J.; Meyers, R.M.; Ho, Y.J.; Kii, E.; Alt, F.W. Genome-wide detection of DNA double-stranded breaks induced by engineered nucleases. Nat. Biotechnol. 2015, 33, 179-186. [CrossRef]

68. Hu, J.H.; Davis, K.M.; Liu, D.R. Chemical biology approaches to genome editing: Understanding, controlling, and delivering programmable nucleases. Cell Chem. Biol. 2016, 23, 57-73. [CrossRef]

69. Hao, F.; Yan, W.; Li, X.; Wang, H.; Wang, Y.; Hu, X.; Liu, X.; Liang, H.; Liu, D. Generation of cashmere goats carrying an EDAR gene mutant using CRISPR-Cas9-mediated genome editing. Int. J. Biol. Sci. 2018, 14, 427-436. [CrossRef]

70. Fan, Z.; Yang, M.; Regouski, M.; Polejaeva, I.A. Gene knockouts in goats using CRISPR/Cas9 system and somatic cell nuclear transfer. Methods Mol. Biol. 2019, 1874, 373-390.

71. Kalds, P.; Zhou, S.; Cai, B.; Liu, J.; Wang, Y.; Petersen, B.; Sonstegard, T.; Wang, X.; Chen, Y. Sheep and goat genome engineering: From random transgenesis to the CRISPR era. Front. Genet. 2019, 10, 750. [CrossRef] 